\title{
Wpływ gospodarki leśnej na terenach górskich na wybrane elementy środowiska - aktualny stan wiedzy \\ Impact of mountain forest management on selected elements of the environment - the current state of knowledge
}

\author{
Andrzej Norbert Affek \\ Instytut Geografii i Przestrzennego Zagospodarowania im. S. Leszczyckiego PAN \\ ul. Twarda 51/55, 00-818 Warszawa \\ a.affek@twarda.pan.pl
}

Zarys treści. W artykule dokonano przeglądu literatury zagranicznej i polskiej dotyczącej wpływu pozyskiwania drewna na wybrane procesy naturalne i elementy środowiska na terenach górskich. Skoncentrowano się przede wszystkim na oddziaływaniu gospodarki leśnej na strukturę gleby i tempo erozji oraz na reakcji hydrologicznej w skali stoku i zlewni, w tym na natężenie i częstotliwość przepływów szczytowych oraz transport fluwialny. Z przeglądu literatury wynika, że zrywka jest tym elementem procesu pozyskiwania drewna, który w największym stopniu oddziałuje na glebę i reakcję hydrologiczną zlewni górskich, a sieć dróg leśnych może przyczyniać się do zwiększenia nawet o kilkanaście procent natężenia przepływów maksymalnych i wynikających z nich powodzi błyskawicznych.

Słowa kluczowe: pozyskanie drewna, góry, przegląd literatury, erozja, wezbrania, transport fluwialny.

\section{Wstęp}

Lasy pokrywają globalnie około $40 \mathrm{mln} \mathrm{km}^{2}$, co stanowi blisko 30\% powierzchni lądów (Cambi i inni, 2015). Charakteryzują się wysoką różnorodnością biologiczną, zarówno roślin, jak i zwierząt oraz grzybów. Świadczą na rzecz człowieka szereg usług ekosystemowych, w tym liczne usługi zaopatrzeniowe (drewno, owoce leśne, grzyby, dziczyzna), regulacyjne (przeciwdziałanie erozji, regulacja klimatu) i kulturowe (stworzenie warunków do rekreacji, edukacji), w efekcie przyczyniając się do budowania dobrostanu człowieka (Krieger, 2001). Do korzystania z części oferowanych przez lasy dóbr niezbędna jest jednak znaczna ingerencja w ekosystem. Dotyczy to w szczególności pozyskania drewna, jednego z najważniejszych surowców dostępnych człowiekowi. Dlatego też jednym z głównych wyzwań współczesnej gospodarki leśnej jest prowadzenie działań w zgodzie z zasadami zrównoważonego rozwoju, czyli takich, które prowadzą do wydajnego wykorzystywania zasobów, a równocześnie minimalizują negatywne oddziaływanie na strukturę i funkcje wszystkich sfer środowiska: atmosfery, biosfery, hydrosfery i litosfery (Heinimann, 2007).

Celem niniejszej pracy jest przedstawienie polskiemu czytelnikowi aktualnego stanu wiedzy na temat wpływu gospodarki leśnej na glebę oraz na obieg wody i materii, w tym na takie zjawiska jak: erozja, transport osadów i powodzie. Praca ta obficie czerpie z zagra- 
nicznych artykułów przeglądowych na temat poszczególnych zagadnień (m.in. Sidle i inni, 2006; Cambi i inni, 2015), równocześnie rozszerzając formułowane tam tezy o doniesienia z nowszych prac, a także publikacji dotyczących warunków polskich.

\section{Gospodarka leśna a gleba ${ }^{1}$}

Jednym z komponentów środowiska, który jest bardzo wrażliwy na niewłaściwe zarządzanie lasami, a w szczególności na działania związane z pozyskiwaniem drewna, jest gleba (Cambi i inni, 2015; Affek i inni, 2017). Odgrywa ona kluczową rolę w ekosystemach leśnych, pośrednicząc w obiegu składników odżywczych oraz przepływach wody i energii, warunkujących produktywność lasów i zachowanie różnorodności biologicznej (Dominati i inni, 2010). System glebowy w wyniku niewłaściwie prowadzonych prac leśnych może ulec znacznym, długotrwałym, a niekiedy nieodwracalnym uszkodzeniom (Hartmann i inni, 2014).

Od lat 50. XX w. powstało wiele prac analizujących wpływ zmechanizowanego pozyskiwania drewna na glebę (Steinbrenner i Gessel, 1955; Greacen i Sands, 1980; Johnson i Beschta, 1980; Adams i Froehlich, 1981; Ballard, 2000; Giannetti i inni, 2017). Jedną z zasadniczych negatywnych konsekwencji zrywki drewna z wykorzystaniem ciężkiego sprzętu jest ściśnięcie gleby (kompakcja) (McNabb i inni, 2001; Ampoorter i inni, 2010). Gleby leśne, często charakteryzujące się biologicznie aktywnymi górnymi poziomami, bogatymi w miękką próchnicę, są szczególnie podatne na to zjawisko (Horn i inni, 2007). Zazwyczaj im bardziej porowata jest gleba, tym większa może być głębokość zagęszczania, sięgająca nawet $450 \mathrm{~mm}$ (Elliot i inni, 1999).

Kompakcja skutkuje spadkiem zdolności infiltracyjnej i przewodnictwa hydraulicznego gleby, co przyczynia się do stagnowania wody na płaskim terenie oraz nasilenia spływu powierzchniowego i erozji wodnej (spłukiwania) na stokach i zboczach dolin (Jansson i Johansson, 1998; Grace i inni, 2006). Efekt ten może wystąpić już po jednokrotnym przejechaniu ciężkim sprzętem po nienaruszonej glebie (Wronski, 1984), a w koleinach dawnych szlaków zrywkowych może utrzymywać się przez wiele lat (Froehlich i inni, 1985; Ezzati i inni, 2012). Przykładowo, E. Zenner i inni (2007) zaobserwowali, że po trzech latach od kompakcji gęstość objętościowa gleby zbliżyła się do stanu pierwotnego jedynie w górnej warstwie, ale nie na głębszych poziomach. Z kolei S. Ezzati i inni (2012) pokazali, że na dawnych szlakach zrywkowych zlokalizowanych w lasach liściastych w górach Iranu nawet po 20 latach gleba brunatna nie odzyskała swoich pierwotnych właściwości (gęstość, porowatość), w szczególności na stromych stokach.

Ponadto, z wyjątkiem grubowarstwowych, przesuszonych gleb, kompakcja zmniejsza dostępność tlenu i wody dla korzeni i mikroorganizmów (Bodelier i inni, 1996; Startsev i McNabb 2000; Frey i inni, 2009), a tym samym prowadzi do obniżenia produktywności lasu (Kozlowski, 1999; Ares i inni, 2005; Agherkakli i inni, 2010). Spadek produktywności został wykazany dla całych powierzchni leśnych (Wert i Thomas, 1981), jak i dla pojedynczych drzew (Froehlich, 1979; Helms i Hipkin, 1986).

\footnotetext{
1 Podrozdział przygotowany głównie na podstawie pracy przeglądowej M. Cambi i innych (2015).
} 


\section{Gospodarka leśna a erozja²}

R. Sidle i inni (2006) zwracają uwagę, aby przy szacowaniu wpływu gospodarki leśnej na erozję gleby wyraźnie rozróżniać erozję wodną (spłukiwanie) od ruchów masowych (np. osuwania się ziemi). Choć spłukiwanie jest procesem naturalnym, to ulega znacznemu nasileniu w wyniku ingerencji człowieka w środowisko (np. zmiana użytkowania ziemi, odsłonięcie gleby, zmiana struktury gleby lub rzeźby terenu) (Kijowska-Strugała i inni, 2018).

W przeciwieństwie do spłukiwania, płytkie, gwałtowne osuwiska to zjawiska epizodyczne uruchamiane przez pojedyncze intensywne opady deszczu (opady nawalne). Natomiast wolniejsze, sięgające daleko w głąb mas skalnych osuwiska inicjują lub aktywują się dopiero po długotrwałej akumulacji wody.

\section{Erozja wodna (spłukiwanie)}

W większości lasów zbliżonych do naturalnych, a także w lasach typowo gospodarczych, zdolność infiltracyjna i przewodnictwo hydrauliczne warstw przypowierzchniowych gleby są stosunkowo wysokie (Sidle i inni, 2006). Wysoka zdolność infiltracyjna wspierana jest przez ciągłe wprowadzanie materii organicznej do gleby. W lasach wolnych od zaburzeń woda opadowa zwykle przenika do gleby i przemieszcza się do potoków w formie przepływu podpowierzchniowego (np. Noguchi i inni, 1997; Douglas i inni, 1999; Sidle i inni, 2006). Tempo erozji gleby w takim lesie jest wyjątkowo niskie i z reguły nie przekracza rocznie 1 t/ha (Elliot i inni, 1999). T. Gerlach (1976) w warunkach polskich (zalesione stoki w Gorcach o nachyleniu $28^{\circ}$ ) uzyskał roczne wielkości spłukiwania jedynie rzędu 1,916,3 kg/ha. Wg W. Elliota i innych (1999) zaburzenia mogą jednak dramatycznie zwiększyć tempo erozji do poziomu przekraczającego 100 t/ha. Do możliwych zaburzeń zaliczają oni zdarzenia i procesy naturalne (pożary i ruchy masowe), jak i te wywołane przez człowieka (budowa dróg i pozyskiwanie drewna).

Wielkość erozji wodnej na zalesionych stokach zależy od pionowego zasięgu zaburzeń związanego z miąższością poziomów organicznych gleby, a także od zasięgu przestrzennego lub łączności zaburzeń (Sidle i inni, 2006). Zakłócenia w dynamice reakcji opad-odpływ (przede wszystkim związane z ograniczeniem zdolności infiltracyjnej gleby) na obszarach, gdzie pozyskiwane jest drewno, będą determinować wielkość potencjalnej erozji wodnej (Malmer, 1996a; Noguchi i inni, 1997). Ponieważ gleby lasów górskich przeważnie charakteryzują się poziomem organicznym o niewielkiej miąższości, naziemne metody zrywki mogą naruszać strukturę gleby, zwiększając w ten sposób ryzyko erozji wodnej (np. Malmer, 1996a; Douglas i inni, 1999). J. Croke i inni (2001) wskazują, że spośród wszystkich działań związanych z gospodarką leśną to właśnie zrywka najbardziej przyczynia się do wzrostu erozji. Najbardziej podatne na erozję są drogi leśne, szlaki zrywkowe i składnice przyzrębowe, czyli miejsca, gdzie gleba jest zbita, odsłonięta i ma głęboko naruszoną strukturę. Sama ścinka i późniejsze prace przy odnowieniu drzewostanu mają niewielki wpływ na erozję wodną, chyba że dojdzie do poważnych i wielkoobszarowych zaburzeń funkcjonowania ekosystemu leśnego.

\footnotetext{
2 Podrozdział przygotowany głównie na podstawie pracy przeglądowej R. Sidlego i innych (2006).
} 
Po intensywnych opadach, w wyniku wysycenia gleby wodą, powstaje spływ powierzchniowy, który, zwłaszcza na drogach gruntowych, gdzie gleba jest sztucznie ściśnięta, przybiera duże rozmiary (Wałdykowski i Krzemień, 2013). Spływ ten jest dodatkowo zasilany w wyniku przechwytywania przepływu podpowierzchniowego z podcięć drogowych (Sidle i inni, 2006). Drogi zwiększają tempo erozji wodnej i przyspieszają spływ wody opadowej do potoków. Badania wykazały, że erozja wodna na szlakach zrywkowych, gdzie występowała kompakcja i znaczne naruszenie struktury gleby, była o ponad trzy rzędy wielkości większa niż na poletkach kontrolnych w sąsiadującym drzewostanie (Hartanto i inni, 2003; Zemke, 2016).

Wielokrotnie wykazano, że drogi leśne i szlaki zrywkowe modyfikują lokalne stosunki wodne, zmniejszając przewodność hydrauliczną i zdolność infiltracji gleby, co powoduje przekierowanie spływu wody i jego koncentrację w różnych częściach zlewni (np. Megahan, 1972; Wemple i inni, 1996). Węzły odprowadzające z dróg ułatwiają dotarcie wody opadowej i osadów nawet do teoretycznie najczystszych źródłowych odcinków potoków górskich.

Dodatkowo, drogi silnie wcięte w stok przechwytują wodę podpowierzchniową i przekierowują ją wzdłuż osi drogi lub do przepustu (np. Megahan, 1972; Wemple i inni, 1996; Negishi i inni, 2008). Skala przechwytywania spływu podpowierzchniowego zależy od występowania i położenia warstw trudno przepuszczalnych. Jeśli warstwa ograniczająca wsiąkanie zostanie odsłonięta w podcięciu drogowym, wówczas większa część przepływu podpowierzchniowego zostanie przechwycona przez drogę.

Warto przy tym odnotować, że stosowane współcześnie na utwardzonych drogach leśnych urządzenia odwadniające z jednej strony mogą ograniczać natężenie niektórych niekorzystnych zjawisk, natomiast z drugiej strony, jeżeli są nieprawidłowo umiejscowione, mogą przyczyniać się do powstania nowych wcięć erozyjnych i osuwisk (np. Sidle i inni, 1985; Piehli inni, 1988; Wemple i inni, 1996). Natomiast na nieutwardzonych i nieposiadających prawidłowo funkcjonujących urządzeń odwadniających górskich drogach leśnych i szlakach zrywkowych spływ powierzchniowy przebiega zgodnie ze spadkiem drogi, a woda wraz z osadami odprowadzana jest w miejscu zmiany spadku na pobliski stok lub bezpośrednio do potoku (Sidle i inni, 2006).

Tam, gdzie naturalne podłoże (gleba) lub sztucznie nasypane podłoże drogi są podatne na erozję, brak systemów odwadniających może mieć katastrofalne skutki, jeśli chodzi o dostawę osadów, szczególnie na stromym terenie. Szczegółowe badania skali erozji na górskich drogach leśnych prowadzone były w latach 90. i pierwszej dekadzie XXI w. w Malezji. Przykładowo, K. Baharuddin i inni (1995) odnotowali ubytki materiału na drogach leśnych i szlakach zrywkowych na poziomie odpowiednio 13,3 i 10,1 t/ha w pierwszym roku po ścince. W drugim roku objętość materiału wyerodowanego spadła do 3,1 i 2,1 t/ha. Znacznie wyższe ubytki gleby zaobserwowali H. Hartanto i inni (2003) i A. Malmer (1996b) na szlakach zrywkowych na Borneo (odpowiednio 30-104 oraz 77-547 t/ha), a także R. Sidle i inni (2004) na Półwyspie Malajskim (275 t/ha). A. Malmer (1996b) odnotował, że roczna dostawa osadów ze szlaków zrywkowych spadła 3-5 razy między pierwszymi dwoma latami po wyrębie w porównaniu do trzeciego roku.

Wyniki różnych badań (np. Sidle i inni, 2004) wskazują, że przy szacowaniu wielkości erozji oprócz gęstości dróg należy uwzględnić także rozkład przestrzenny sieci drogowej, topografię terenu i rodzaj podłoża. Przykładowo, M. Akbarimehr i H. Jalilvand (2013) wykazali, że erozja jest większa na silnie nachylonych stokach i na słabo związanym podłożu 
(np. na fliszu). Również prowadzenie dróg zgodnie ze spadkiem stoku i bezpośrednie przecinanie się dróg i potoków dodatkowo wzmaga erozję i depozycję osadów do potoków (Bucała-Hrabia, 2018).

Podsumowując powyższy rozdział należy podkreślić, że przełożenie wykazanych prawidłowości na warunki polskie, a nawet europejskie, może być utrudnione, gdyż większość cytowanych prac odnosi się do regionów o odmiennych charakterystykach środowiskowych, choćby klimatycznych. Co prawda w Polsce ukazało się wiele prac dotyczących roli dróg w procesie kształtowania spływu i erozji w zlewniach górskich (np. Froehlich i Słupik, 1986; Kroczak, 2010), jednak w ogromnej większości prace te nie dotyczą dróg wykorzystywanych w gospodarce leśnej, tylko dróg polnych lub całej sieci drogowej w wybranej zlewni. Niemniej jednak kilka prac z Europy Środkowej powstałych w ostatnich latach także jednoznacznie pokazuje wpływ dróg leśnych i szlaków zrywkowych na wzrost spływu powierzchniowego i zwiększenie tempa erozji wodnej (np. Butzen i inni, 2014; Zemke, 2016).

\section{Ruchy masowe}

W przeciwieństwie do tempa/dynamiki erozji wodnej, tempo erozji osuwiskowej (ruchów masowych) zaczyna istotnie rosnąć dopiero kilka lat po pozyskaniu drewna (Sidle i inni, 2006). Głęboko zakorzenione drzewa i krzewy podwyższają spoistość płytkiej pokrywy glebowej i ułatwiają odwadnianie, zmniejszając w ten sposób prawdopodobieństwo płytkich osuwisk. Pozyskanie drewna z późniejszym odnowieniem drzewostanu zmniejsza siłę stabilizującą korzeni (ang. rooting strength) do dwóch dekad po ścince drzew. W licznych badaniach terenowych prowadzonych na całym świecie w stromym, zalesionym terenie odnotowano znaczący (aż do dziesięciokrotnego) wzrost aktywności osuwisk w okresie 3-15 lat po pozyskaniu drewna (Bishop i Stevens, 1964; Endo i Tsuruta, 1969; O'Loughlin i Pearce, 1976; Wu i Sidle, 1995; Jakob, 2000; Sakals i Sidle, 2004). Wzrost następuje zarówno w zakresie częstotliwości, jak i objętości osuwisk i jest w dużej mierze związany z okresem, w którym siła stabilizująca korzeni osiąga minimalne wartości, co spowodowane jest stopniowym pogarszaniem się wytrzymałości korzeni ściętych drzew przy jednocześnie słabo rozwiniętym systemie korzeniowym młodych drzew.

Badania terenowe prowadzone na całym świecie wykazały, że osuwanie się ziemi na drogach leśnych jest średnio 25-350 razy większe niż w lasach wolnych od zaburzeń (np. O'Loughlin, 1972; O'Loughlin i Pearce, 1976; Gray i Megahan, 1981; Amaranthus i inni, 1985). Szacowane średnie tempo osuwania się ziemi wywołane użytkowaniem dróg leśnych w stromym terenie wynosi rocznie od 3,5 do 334 t/ha, przy czym większość wartości mieści się w przedziale 20-45 t/ha. Jedno z nielicznych kompleksowych badań osuwisk związanych z istnieniem dróg leśnych wykazało, że powierzchnia osuwisk powstałych pod wpływem dróg była 5-8 razy większa niż osuwisk niezwiązanych z istnieniem dróg (Larsen i Parks, 1997).

Osuwiska związane z drogami, tak jak inne osuwiska, występują najczęściej po intensywnych opadach atmosferycznych, ale mogą również wystąpić w dowolnym czasie po powstaniu drogi (Sidle i inni, 1985; Douglas i inni, 1999; Chappell i inni, 2004). Zmiany w stosunkach wodnych na stokach górskich wywołane przez drogi istotnie wpływają na stabilność tych stoków. System odwadniania drogi leśnej kierujący wodę celowo lub przypadkowo na fragment zbocza może potencjalnie zwiększyć ciśnienie wody porowej (woda wypełniająca przestrzeń między cząstkami osadu i gleby) w trakcie intensywnych opadów 
(Megahan, 1972, 1983; Douglas i inni, 1999). Nawet przy prawidłowo skonstruowanych drogach, zbyt mało przepustów lub ich złe umiejscowienie może prowadzić do wzrostu ciśnienia wody porowej w glebie poniżej drogi (Burroughs, 1984; Piehl i inni, 1988).

Obszary szczególnie podatne na ruchy masowe to naturalne wgłębienia na stokach, które gromadzą wodę podpowierzchniową i gdzie już wcześniej odnotowano ślady erozji osuwiskowej (np. Tsukamoto i Ohta, 1988; Sidle, 2006). Drenaż kierujący wodę do tych naturalnie wilgotnych i niestabilnych zagłębień, jak również drogi bezpośrednio przez nie przechodzące, są głównymi przyczynami osunięć ziemi (np. LaHusen, 1984).

W stromym terenie drogi leśne prowadzące w poprzek stoku (drogi stokowe, tzw. trawersy) mają na ogół największy destabilizujący wpływ z powodu przechwytywania wód podpowierzchniowych oraz przeciążania i podcinania stoków (Douglas i inni, 1999). Niemniej, D. Montgomery (1994) zauważyła, że koncentracja odpływu z dróg przebiegających wzdłuż grzbietu może również przyczynić się do inicjacji osuwisk. Można więc przyjąć, że każdy system odwadniania drogi, który koncentruje odpływ na strome zbocza, do lokalnych zagłębień lub wprost na koronę drogi, znacznie zwiększa prawdopodobieństwo osunięcia się zbocza. Na obszarach, gdzie drogi są silnie wcięte w strome stoki i nie posiadają odpowiedniego odwodnienia, prawdopodobieństwo powstania osuwisk jest bardzo wysokie (np. Thakur, 1996; Douglas i inni, 1999).

Trudno sobie współcześnie wyobrazić prowadzenie jakiejkolwiek gospodarki leśnej bez dróg leśnych. Natomiast to, jak będą one oddziaływały na stabilność stoków w terenie górskim w dużej mierze zależy od prawidłowej konstrukcji sieci drogowej i samych dróg. Do zmiennych o największym znaczeniu należą: długość dróg w stromym terenie, długość i szerokość dróg trawersujących strome zbocza, ilość przechwytywanej wody oraz sposób i miejsce jej odprowadzania, identyfikacja obszarów o niestabilnym podłożu (np. naturalnych wgłębień lub dawnych osuwisk), projekt i jakość wykonania drogi, a także sposób ostatecznego użytkowania i konserwacji (Sidle i inni, 1985; Megahan, 1987; Allison i inni, 2004).

\section{Gospodarka leśna a występowanie powodzi}

Zdaniem T. Bryndala (2014) wiedza na temat formowania odpływu w zlewniach zalesionych jest wciąż niewielka. Wiadomo natomiast, że znaczna lesistość zlewni może zmniejszać częstość występowania wezbrań powodowanych przez małej i średniej wielkości opady, natomiast nie zabezpiecza przed występowaniem gwałtownych wezbrań (Beschta i inni, 2000). W analizie wpływu zmiany pokrywy leśnej na występowanie powodzi kluczowe są dwa aspekty: (1) zmiana wielkości przepływu dla zdarzeń o określonej częstotliwości występowania i, co ważniejsze, (2) zmiana częstotliwości występowania zdarzeń o określonej wielkości przepływu (Green i Alila, 2012).

Najpopularniejszą metodą badania pierwszego aspektu tej relacji jest metoda tzw. zlewni bliźniaczych (ang. paired watershed method) (patrz: Clausen i Spooner, 1993). W podejściu tym dobiera się dwie lub więcej zlewni o możliwie zbliżonych warunkach naturalnych i po okresie kalibracji prowadzi się w ich obrębie (za wyjątkiem jednej zlewni kontrolnej) działania eksperymentalne, przeważnie związane ze zmianą pokrywy leśnej, np. na skutek pozyskania drewna. Zdaniem K. Green i Y. Alili (2012) metoda ta nie nadaje się do analizy drugiego aspektu, który może być prawidłowo rozpoznany jedynie poprzez wieloletnie badania monitoringowe polegające na bezpośrednim porównaniu serii zda- 
rzeń powodziowych występujących przed i po wprowadzeniu czynnika modyfikującego (np. wycinki).

Istnieje bogata literatura opisująca skutki hydrologiczne cięć eksperymentalnych, w szczególności w zlewniach bliźniaczych o niewielkiej powierzchni $\left(<2 \mathrm{~km}^{2}\right)$ (patrz: Bosch i Hewlett, 1982; Stednick, 1996; Andréassian, 2004; Brown i inni, 2005). Przykładowo, J. Jones i G. Grant (1996) na podstawie wieloletnich ciągów pomiarowych (od 34 do 55 lat) z pięciu par zlewni bliźniaczych o powierzchni od 0,6 do 600 km² w Górach Kaskadowych w stanie Oregon stwierdzili, że pozyskanie drewna zwiększa przepływy szczytowe nawet o 50\% w małych zlewniach oraz o 100\% w dużych zlewniach.

Na podstawie przeglądu tych badań można stwierdzić, że pozyskanie drewna zwiększa roczny odpływ wód ze zlewni, szczególnie w klimacie umiarkowanym (Bosch i Hewlett, 1982; Brown i inni, 2005). J. Biederman i inni (2015) zauważają jednak, że tę zależność wykazano jedynie wówczas, gdy spełnione były poniższe warunki:

1. średni roczny opad przekraczał wartość progową (zwykle ok. 450-500 mm), poniżej której większość opadu wyparowuje,

2. pozyskanie drewna lub innego typu zaburzenie obejmowało co najmniej $20 \%$ drzewostanu (pierśnicowego pola przekroju, ang. basal area).

Klasyczne badania na zlewniach bliźniaczych pokazują ponadto, że zwiększenie przepływu jest spodziewane przede wszystkim w latach bezpośrednio po wycince, choć maksymalny czas trwania tego efektu może wynosić od 5 do 50 lat, a nawet dłużej. Należy przy tym spodziewać się mniejszego wzrostu przepływu, gdy zaburzenie jest rozproszone w przestrzeni. Tak się dzieje np. gdy zamiast całkowitego usunięcia drzew stosuje się cięcia trzebieżowe lub rębnie stopniowe gniazdowe (Biederman i inni, 2015).

W ostatnim czasie badania prowadzone na zlewniach bliźniaczych spotykają się z coraz szerszą krytyką (patrz: Alila i inni, 2009; Green i Alila, 2012; Kuraś i inni, 2012). Dotyczy ona przede wszystkim tego, że na ich podstawie nie można wnioskować na temat zmiany częstotliwości występowania wielkich powodzi (mających największe znaczenie dla funkcjonowania ludzi i ekosystemów), a także na temat zmiany przepływów w większych rzekach. Ponadto, P. Kuraś i inni (2012) zwrócili uwagę, że to klasyczne podejście badawcze nie daje możliwości odrębnego analizowania znaczenia poszczególnych aspektów gospodarki leśnej oraz w praktyce ogranicza się do badania wpływu samego pozyskiwania drewna.

W skali globalnej związek między gospodarka leśną, w tym drogami leśnymi, a maksymalnymi przepływami został najlepiej rozpoznany w Górach Kaskadowych. Ze względu na wystąpienie w tym samym czasie spadku liczebności łososia i kilku dużych powodzi (m.in. po opadach nawalnych z listopada 1990 r. i lutego 1996 r.), w drugiej połowie lat 90. zaczęto się przyglądać możliwym skutkom hydrologicznym coraz bardziej zmechanizowanej i prowadzonej w sposób intensywny gospodarki leśnej. Dogłębną analizę wpływu gospodarki leśnej na obieg wody w zlewni, w tym na wielkość przepływów szczytowych, zaprezentowali J. La Marche i D. Lettenmaier (2001). Autorzy zaproponowali dwie ogólne grupy mechanizmów, poprzez które gospodarka leśna może oddziaływać na spływ powierzchniowy. Pierwszym z nich jest bezpośredni wpływ usuwania roślinności na zmianę przemieszczania się i akumulacji wilgoci w pobliżu powierzchni ziemi. W skali stoku usuwanie drzew zmniejsza intercepcję zarówno w przypadku opadu ciekłego, jak i stałego (śnieg). Usuwanie roślinności i ograniczenie zbiornika intercepcji skutkuje także wyż-

\footnotetext{
3 Intercepcja - proces zatrzymywania wody opadowej (np. przez szatę roślinną), na skutek którego zmniejsza się dopływ wody do powierzchni ziemi i zwiększa się czas jej dopływu.
} 
szą infiltracją wód opadowych, a tym samym zwiększa wilgotność gleby. Zredukowana ewapotranspiracja (ET) występująca podczas odnawiania drzewostanu również wpływa na zwiększenie wilgotności gleby (Anderson i inni, 1976; Megahan, 1983).

Drugą, słabiej rozpoznaną grupą mechanizmów, za pomocą których gospodarka leśna może oddziaływać na reakcję hydrologiczną systemów górskich, są zmiany w funkcjonowaniu systemu odprowadzania wody spowodowane występowaniem dróg leśnych (La Marche i Lettenmaier, 2001). Zdaniem m.in. J. Jones i G. Granta (1996) zmiany przepływu wód związane z drogami leśnymi mogą mieć większe znaczenie niż te związane bezpośrednio z usuwaniem roślinności.

Istnieją co najmniej dwa rodzaje potencjalnego, bezpośredniego oddziaływania dróg leśnych na reakcję hydrologiczną zlewni (La Marche i Lettenmaier, 2001): (1) nasilenie spływu powierzchniowego na utwardzonej nawierzchni drogi (ew. ściśniętej glebie) ze względu na zredukowane tempo infiltracji i (2) przechwytywanie spływu podpowierzchniowego przez wcięcia drogowe.

Spływ powierzchniowy formowany na utwardzonych drogach leśnych przez oba powyższe mechanizmy jest zazwyczaj odprowadzany przez przydrożne rowy do sieci rzecznej. Z dróg woda opadowa trafia do przepustów drogowych (na potokach lub tzw. burzowych) lub do wodospustów (urządzeń melioracyjnych umożliwiających odprowadzanie wody opadowej z korony drogi), a w dalszej kolejności do wąwozów bądź sztucznych kanałów połączonych z ciekami naturalnymi. Może to modyfikować mechanizm i czas przepływu wody ze stoku do sieci rzecznej z powolnego spływu podpowierzchniowego zgodnego z prawem Darcy'ego ${ }^{4}$ do szybkiego spływu powierzchniowego. Z drugiej strony, spływ powierzchniowy przechwycony przez sieć drogową może infiltrować w miejscach odprowadzania z niej wody, a wówczas zmiany w reakcji hydrologicznej zlewni mogą być minimalne (La Marche i Lettenmaier, 2001).

Oprócz efektów czasowych J. Jones i G. Grant (1996) sugerowali, że między drogami leśnymi a pozyskaniem drewna może występować efekt synergii związany z ich równoczesnym oddziaływaniem na obieg wody. Podwyższony poziom wody podziemnej na obszarach pozyskania drewna ulokowanych powyżej dróg leśnych powinien prowadzić do przechwytywania większej ilości wód podpowierzchniowych z wcięć drogowych w porównaniu z obszarami, gdzie aktualnie nie prowadzi się pozyskania. Zwiększona objętość przechwyconej wody jest następnie transportowana przez drogowy system odwadniania do potoków. Wreszcie, drogi mogą obniżyć zwierciadło wód podziemnych i ograniczyć spływ powierzchniowy poniżej drogi poprzez przechwycenie części spływu podpowierzchniowego powyżej drogi (La Marche i Lettenmaier, 2001). L. Bowling i D. Lettenmaier (1997) wykazali poprzez modelowanie możliwość wystąpienia tego efektu w dwóch małych zlewniach w dorzeczu rzeki Deschutes w stanie Oregon (USA).

Podsumowując, badania J. La Marche'a i D. Lettenmaiera (2001), bazujące na wieloletnich obserwacjach terenowych prowadzonych w Górach Kaskadowych, wykazały wyższe przepływy w przydrożnych rowach odwadniających zręby w stosunku do terenów zalesionych. Wyniki te sugerują, że może istnieć interakcja między oddziaływaniem pokrywy leśnej i sieci drogowej na spływ powierzchniowy w górach. Przeprowadzone modelowanie hydrologiczne wpływu dróg na przepływy szczytowe w dziewięciu zlewniach elementarnych przyniosło szereg wniosków.

\footnotetext{
4 Prawo (formuła) Darcy'ego - fundamentalny wzór o charakterze fenomenologicznym, opisujący zależność między prędkością filtracji płynu przepływającego w ośrodku porowatym a gradientem ciśnienia.
} 
1. Drogi leśne przyczyniają się do zwiększenia średnich rocznych przepływów szczytowych od 2,2 do 9,5\% oraz od 2,9 do 12,2\% w przypadku powodzi dziesięciolecia. Największe wzrosty natężenia przepływów związane z drogami leśnymi (bez uwzględnienia efektów pozyskiwania drewna) są w przybliżeniu porównywalne ze wzrostami wynikającymi z samego pozyskiwania drewna.

2. Przewidywane przez model wzrosty natężenia fali powodziowej spowodowane istnieniem dróg leśnych są na ogół proporcjonalne do wielkości powodzi.

3. Wpływ dróg leśnych i pozyskania drewna na przepływy szczytowe na poziomie zlewni jest zasadniczo niezależny, więc ich łączny efekt ma charakter addytywny.

4. W skali stoku rzeczywista, jak i modelowa reakcja hydrologiczna rowów przydrożnych jest zależna od stanu roślinności, z wyższymi przepływami notowanymi w rowach odwadniających obszary pozyskania drewna. Brak takiej synergii na poziomie zlewni najprawdopodobniej wynika z desynchronizacji przepływów szczytowych na poziomie poszczególnych stoków.

Interesujące wyniki metaanalizy dotyczącej związku gospodarki leśnej z częstotliwością występowania powodzi, choć uzyskane dla zlewni zasilanych głównie topniejącym śniegiem, uzyskali K. Green i Y. Alila (2012). Poza wzrostem natężenia średnich rocznych przepływów szczytowych wykazali oni, że od 2 do 4 razy wzrosła częstotliwość zjawisk powodziowych o największym nasileniu, opisywanych jako powodzie pięćdziesięciolecia, w okresie bezpośrednio po wycince lasu. Autorzy także potwierdzili wcześniejsze doniesienia (Troendle i King, 1985) mówiące o tym, że powrót systemu hydrologicznego do stanu sprzed wycinki jest niezwykle powolny i może zająć nawet 80 lat. Warto przy tym odnotować, że inżynierowie w USA już na początku XX w. (Hoyt i Troxell, 1932) podejrzewali, że częstotliwość katastrofalnych powodzi zwiększy się z powodu pozyskiwania drewna na obszarach górskich.

Wpływ zmiany pokrywy leśnej na występowanie powodzi można rozpatrywać nie tylko analizując ubytek lasu, ale także wzrost jego udziału w powierzchni zlewni. Przykładowo, B. Ortyl i inni (2018) dostrzegli znaczny spadek średniego poziomu wody (nie analizowali stanów maksymalnych) w latach 1935-2012 w rzece Jasiołce w Karpatach i powiązali go ze wzrostem lesistości zlewni wynikającym z wysiedleń i porzucania działalności rolniczej. Podobnie R. Soja (2002) wskazuje na wyraźny spadek powodziowości (częstości występowania wysokich stanów wody) w dorzeczu górnej Wisły w drugiej połowie XX w., jednak nie podejmuje się na podstawie swoich badań wskazać czynników odpowiedzialnych za ten spadek. Natomiast wśród czynników antropogenicznych mających istotny wpływ na obieg wody w karpackich zlewniach autor ten wymienia nadmierną eksploatację lasów i niezgodne z siedliskowymi uwarunkowaniami wprowadzanie monokultur leśnych.

Co ciekawe, badania prowadzone w ostatnim dziesięcioleciu, zarówno bazujące na obserwacjach, jak i na bardziej zaawansowanym modelowaniu, nie potwierdzają wcześniej wykazywanych związków redukcji pokrywy roślinnej ze wzrostem przepływów w zlewniach górskich (Kuraś i inni, 2012; Biederman i inni, 2015; Slinski i inni, 2016). Warto jednak zaznaczyć, że analizowana w wyżej wymienionych pracach redukcja pokrywy roślinnej nie zawsze wynikała z działalności człowieka, ale była rezultatem naturalnych zaburzeń, w tym głównie gradacji kornika (Biederman i inni, 2015; Slinski i inni, 2016). Tym niemniej, P. Kuraś i inni (2012) jednoznacznie wykazali na podstawie modelowania, że pozyskanie drewna na poziomie nawet 30\% drzewostanu nie wpłynie istotnie na wielkość przepływów szczytowych. Wyniki ich pracy pokazują, jak trudno jest sformułować uniwersalne, 
prawdziwe w każdym wypadku wnioski, dotyczące funkcjonowania złożonych systemów przyrodniczych. Obecnie potrzeba silniejszych dowodów na to, aby wykazywany przez dziesięciolecia w setkach prac związek pozyskania drewna ze wzrostem odpływu wody ze zlewni podważyć.

\section{Gospodarka leśna a dostawa osadów do systemu korytowego}

Produkty wietrzenia i erozji wynoszone są ze zlewni poprzez transport fluwialny w formie materiału rozpuszczonego, zawiesiny i klastycznych zwietrzelin (Froehlich, 1975). Na materiał transportowany przez wody potoków górskich składają się osady dostarczane przez dopływy oraz materiał budujący dno i brzegi koryta, wypełniający dna dolin oraz dostarczany ze stoków. Wielu badaczy wskazuje także drogi nieutwardzone jako źródło dostawy materiału transportowanego (np. Froehlich, 1982; Kroczak, 2010; Kijowska-Strugała, 2015). Ponadto, drogi stanowią również łącznik pomiędzy systemem stokowym i korytowym, dostarczając znacznych ilości drobnego materiału bezpośrednio do koryta rzecznego (Froehlich i Walling, 1997).

W celu określenia dodatkowej ilości osadów wynoszonych w wyniku prowadzenia gospodarki leśnej (w tym budowy dróg leśnych) badano zlewnie górskie o zróżnicowanych warunkach naturalnych w wielu zakątkach świata (Fredriksen, 1970; Brown i Krygier, 1971; Beschta, 1978). W punktach zamykających zlewnie, na terenie których pozyskiwano drewno, regularnie odnotowywano znaczące wzrosty objętości zarówno osadów zawieszonych, jak i rumowiska wleczonego (Malmer, 1996a, b; Douglas i inni, 1999). Wyniki badań szczegółowych jasno wskazują, że w terenach górskich to nie sam obszar ścinki, a gruntowe drogi leśne, szlaki zrywkowe i obszary składowania drewna stanowią pierwotne źródła osadów (Sidle i inni, 1985, 2004, 2006; Baharuddin i inni, 1995; Malmer, 1996b; Froehlich i Walling, 1997; Larsen i Parks, 1997; Wemple i inni, 2001). Przykładowo, badania L. Reid (1981) w górach Olympic (USA) wskazują, że prawie 40\% wszystkich osadów wynoszonych w formie transportu fluwialnego z całkowicie zalesionej i intensywnie eksploatowanej zlewni związanych jest z drogami leśnymi.

Wieloletnie badania nad rolą dróg w dostawie materiału do koryta prowadzone były także w Karpatach pod kierunkiem W. Froehlicha. Wykazały one, że w testowej zlewni w Beskidzie Sądeckim aż 80\% materiału transportowanego w rzece w formie zawieszonej pochodzi z nieutwardzonych dróg, przy średnim tempie ich pogłębiania około 6,6 mm rocznie (Froehlich, 1982; Froehlich i Walling, 1997). Zdaniem autorów zmniejszenie ilości transportowanego materiału zawieszonego może nastąpić, gdy znacząco zmniejszy się gęstość dróg na stokach (Froehlich i Walling, 1997).

Szereg zmiennych wpływa na ilość materiału erodowanego z powierzchni dróg leśnych. W badaniu przeprowadzonym w północnej części Gór Skalistych w Stanach Zjednoczonych wyodrębniono 14 czynników, które miały największy wpływ na rozwój tzw. żłobków deszczowych na drogach (Packer, 1967). Dwoma najważniejszymi były nachylenie oraz wielkość cząstek materiału budującego drogę. Z kolei badania w Appalachach wykazały, że miąższość, skład oraz rozmiar cząstek materiału tworzącego nawierzchnię drogi są najistotniejszymi czynnikami modyfikującymi ilość transportowanych osadów (Swift, 1984a; Kochenderfer i Helvey, 1987). Ponadto, intensywność ruchu i charakterystyka pojazdów stosowanych do zrywki drewna wpływają na wiele parametrów fizycznych dróg istotnych 
dla dostawy osadów (Reid, 1981; Reid i Dunne, 1984; Swift, 1984b; Bilby i inni, 1989). Z obserwacji L. Reid i T. Dunne'a (1984) wynika, że ruch pojazdów powoduje kruszenie i rozdrobnienie cząstek materiału i wzmożone wynoszenie osadów z powierzchni drogi. Dotyczy to również dróg utwardzonych żwirem, gdzie podczas ruchu ciężkich pojazdów produkowana jest znaczna ilość drobnoziarnistego materiału łatwo ulegającego transportowi fluwialnemu. Wyniki badań tych autorów wskazują, że intensywnie użytkowana droga gruntowa jest źródłem 130 razy większej ilości osadów niż droga nieużytkowana. Natomiast droga asfaltowa, wzdłuż której jedynie wcięcia drogowe i rowy są źródłem osadów, dostarcza mniej niż 1\% materiału wynoszonego z intensywnie użytkowanej drogi żwirowej (Reid i Dunne, 1984).

Użytkowanie drogi ciężkim sprzętem często skutkuje powstawaniem kolein, zwiększając tym samym erozję i transport osadów (Fahey i Coker, 1989; Foltz i Burroughs, 1990; Haydon i inni, 1991). Profilowanie nawierzchni drogi w celu wyeliminowania koncentracji spływu powierzchniowego w koleinach lub żłobkach deszczowych z reguły zmniejsza transport osadów, choć zabiegi te mogą również niszczyć twarde, odporne na erozję podłoże i w ten sposób zwiększać ilość luźnego materiału. Inne zmienne, które mogą znacząco wpływać na transport osadów, to intensywność i czas trwania opadów oraz ciśnienie w oponach pojazdów stosowanych do zrywki (Megahan i Kidd, 1972; Reid, 1981; Kochenderfer i Helvey, 1987).

Warto też zaznaczyć, że procesy spływu i erozji na drogach nieutwardzonych często powodują ich przekształcenie w debrze, wciosy lub wąwozy, w zależności od podłoża, na jakim powstają (Kroczak, 2010), w efekcie uniemożliwiając ich dalszą eksploatację. Skutkiem takich procesów jest pojawienie się niekorzystnego zjawiska dróg równoległych (Affek i inni, 2017).

Choć utwardzanie dróg leśnych ogranicza procesy wietrzenia i erozji w ich obrębie, to w czasie opadów i tak transportują one materiał pochodzący z dróg nieutwardzonych, który jest następnie spłukiwany i w szybkim tempie dostarczany do koryta. Wzrost sieci dróg utwardzonych w Karpatach w ostatnim dwudziestoleciu w znaczący sposób przyczynił się również do rozwoju sieci rowów przydrożnych, erodowanych w czasie intensywnych opadów deszczu, które obok dróg stanowią bardzo ważne źródło materiału transportu fluwialnego (Kijowska-Strugała, 2015).

\section{Podsumowanie}

Przeprowadzony przegląd literatury daje podstawy do sformułowania następujących wniosków:

1. gospodarka leśna, a przede wszystkim powstałe w jej wyniku drogi leśne i szlaki zrywkowe przyspieszają erozję wodną i procesy osuwiskowe na terenach górskich;

2. przemieszczanie się materii wzdłuż dróg leśnych (zarówno w wyniku erozji, jak i osunięć mas ziemi) jest zwykle o jeden do ponad dwóch rzędów wielkości wyższe od tego, które ma miejsce na stromych zalesionych stokach;

3. gruntowe drogi leśne, szlaki zrywkowe i obszary składowania drewna stanowią główne źródła osadów na terenach leśnych, a drogi utwardzone przyczyniają się do zwiększenia/przyspieszenia spływu powierzchniowego; 
4. charakter i lokalizacja górskich dróg leśnych w znaczącym stopniu wpływają na to, jak intensywnie będą przebiegać procesy erozji wodnej i osuwania się ziemi, a także jak duże będą przepływy szczytowe i wynikające z nich zagrożenie powodziowe w niższych położeniach;

5. prowadzenie dróg i szlaków zrywkowych zgodnie ze spadkiem stoku i bezpośrednie przecinanie się dróg i potoków dodatkowo nasila erozję i depozycję osadów do potoków;

6. sieć dróg leśnych może przyczyniać się do zwiększenia natężenia przepływów maksymalnych i wynikających z nich powodzi błyskawicznych nawet o kilkanaście procent;

7. w okresie bezpośrednio po wycince lasu można się spodziewać, że od 2 do 4 razy wzrośnie częstotliwość zjawisk powodziowych o największym nasileniu;

8. roczny odpływ wód ze zlewni z reguły zwiększa się istotnie przy pozyskaniu drewna na poziomie powyżej 20\% drzewostanu;

9. powrót systemu hydrologicznego do stanu sprzed wycinki jest niezwykle powolny i może zająć nawet 80 lat;

10. część badań prowadzonych w ostatnim dziesięcioleciu nie potwierdza wcześniej wykazywanych związków wzrostu przepływów w zlewniach górskich z redukcją pokrywy roślinnej.

Niniejszy artykuł jest modyfikacją i rozszerzeniem pierwszej części opracowania Wpływ współczesnej gospodarki leśnej na erozję i występowanie powodzi w niższych położeniach - aktualny stan wiedzy i oszacowanie skali zjawiska we wschodniej części polskich Karpat na podstawie danych leśnych i danych LiDAR, wykonanego na zlecenie Fundacji Dziedzictwo Przyrodnicze i sfinansowanego ze środków WWF Polska.

\section{Piśmiennictwo}

Adams P., Froehlich H., 1981, Compaction of Forest Soils, PNW, 217, A Pacific Northwest Extension Publication, Oregon, Washington, Idaho.

Affek A., Zachwatowicz M., Sosnowska A., Gerlée A., Kiszka K., 2017, Impacts of modern mechanised skidding on the natural and cultural heritage of the Polish Carpathian Mountains, Forest Ecology and Management, 405, s. 391-403.

Agherkakli B., Najafi A., Sadeghi S., 2010, Ground based operation effects on soil disturbance by steel tracked skidder in a steep slope of forest, Journal of Forest Science, 56, s. 278-284.

Akbarimehr M., Jalilvand H., 2013, Considering the relationship of slope and soil loss on skid trails in the north of Iran (a case study), Journal of Forest Science, 59, s. 339-344.

Alila Y., Kuraś P.K., Schnorbus M., Hudson R., 2009, Forests and floods: A new paradigm sheds light on age-old controversies, Water Resources Research, 45, s. 1-24.

Allison C., Sidle R.C., Tait D., 2004, Application of decision analysis forest road deactivation in unstable terrain, Environmental Management, 33, s. 173-185.

Amaranthus M.P., Rice R.M., Barr N.R., Ziemer R.R., 1985, Logging and forest roads related to increased debris slides in southwestern Oregon, Journal of Forestry, 83, s. 229-233. 
Ampoorter E., Van Nevel L., De Vos B., Hermy M., Verheyen K., 2010, Assessing the effects of initial soil characteristics, machine mass and traffic intensity on forest soil compaction, Forest Ecology and Management, 260, s. 1664-1676.

Anderson H.W., Hoover M.D., Reinhart K.G., 1976, Forests and water: Effect of forest management on floods, sedimentation, and water supply. General Technical Report PSW-18/1976, USDA Forest Service, Washington DC.

Andréassian V., 2004, Waters and forests: From historical controversy to scientific debate, Journal of Hydrology, 291, s. 1-27.

Ares A., Terry T., Miller R., Anderson H., Flaming B., 2005, Ground-based forest harvesting effects on soil physical properties and Douglas-fir growth, Soil Science Society of America Journal, 69, s. 1822-1832.

Baharuddin K., Mokhtaruddin A.M., Nik Muhamad M., 1995, Surface runoff and soil loss from a skid trail and a logging road in a tropical forest, Journal of Tropical Forest Science, 7, s. 558-569.

Ballard T.M., 2000, Impacts of forest management on northern forest soils, Forest Ecology and Management, 133, s. 37-42.

Beschta R.L., 1978, Long-term patterns of sediment production following road construction and logging in the Oregon Coast Range, Water Resources Research, 14, 6, s. 1011-1016.

Beschta R.L., Pyles M.R., Skaugset A.E., Surfleet C.G., 2000, Peakflow responses to forest practices in the Western Cascades of Oregon, USA, Journal of Hydrology, 233, 1-4, s. 102-112.

Biederman J.A., Somor A.J., Harpold A.A., Gutmann E.D., Breshears D.D., Troch P.A., Gochis D.J., Scott R.L., Meddens A.J.H., Brooks P.D., 2015, Recent tree die-off has little effect on streamflow in contrast to expected increases from historical studies, Water Resources Research, 51, s. 9775-9789.

Bilby R.E., Sullivan K., Duncan S.H., 1989, The generation and fate of road-surface sediment in forested watersheds in southwestern Washington, Forest Science, 35, 2, s. 453-468.

Bishop D.M., Stevens M.E., 1964, Landslides on logged areas, southeast Alaska. Northern Forest Experiment Station Research Paper NOR-1, USDA Forest Service, Juneau, Alaska.

Bodelier P., Libochant J.A., Blom C., Laanbroek H., 1996, Dynamics of nitrification and denitrification in root-oxygenated sediments and adaptation of ammonia oxidizing bacteria to low-oxygen or anoxic habitats, Applied and Environmental Microbiology, 11, s. 4100-4107.

Bosch J.M., Hewlett J.D., 1982, A Review of Catchment Experiments to Determine the Effect of the Vegetation Changes on Water Yield and Evapotranspiration, Journal of Hydrology, 55, s. 3-23.

Bowling L.C., Lettenmaier D.P., 1997, Evaluation of the effects of forest roads on streamflow in Hard and Ware Creeks, Washington. Water Resources Series Technical Report No. 155, Department of Civil Engineering, University of Washington, Seattle, WA.

Brown A.E., Zhang L., McMahon T.A., Western A.W., Vertessy R.A., 2005, A review of paired catchment studies for determining changes in water yield resulting from alterations in vegetation, Journal of Hydrology, 310, s. 28-61.

Brown G.W., Krygier J.T., 1971, Clear-cut logging and sediment production in the Oregon Coast Range, Water Resources Research, 7, 5, s. 1189-1198.

Bryndal T., 2014, Identyfikacja małych zlewni podatnych na formowanie gwałtownych wezbrań w Karpatach Polskich, Prace Monograficzne, 690, Wydawnictwo Naukowe UP, Kraków.

Bucała-Hrabia A., 2018, The role of unmetalled roads as a sediment source in the fluvial systems of the Polish Flysch Carpathians, human impacts on erosion and sedimentation, Geographia Polonica, 91, 2, s.171-196. 
Burroughs E.R., 1984, Survey of slope stability problems on forest lands in the west, [w:] Proceedings of a Workshop on Slope Stability: Problems and Solutions in Forest Management. General Technical Report PNW-180, USDA Forest Service, Pacific Northwest Research Station, Portland, OR, s. 5-16.

Butzen V., Seeger M., Wirtz S., Huemann M., Mueller C., Casper M., Ries J.B., 2014, Quantification of Hortonian overland flow generation and soil erosion in a Central European low mountain range using rainfall experiments, Catena, 113, s. 202-212.

Cambi M., Certini G., Neri F., Marchi E., 2015, The impact of heavy traffic on forest soils: A review, Forest Ecology and Management, 338, s. 124-138.

Chappell N.A., Douglas I., Hanapi J.M., Tych W., 2004, Sources of suspended sediment within a tropical catchment recovering from selective logging, Hydrological Processes, 18, s. 685-710.

Clausen J.C., Spooner J., 1993, Paired watershed study design, Office of Water, U.S. Environmental Protection Agency, Washington DC.

Croke J., Hairsine P., Fogarty P., 2001, Soil recovery from track construction and harvesting changes in surface infiltration, erosion and delivery rates with time, Forest Ecology and Management, 143, s. 3-12.

Dominati E., Patterson M., Mackay A., 2010, A framework for classifying and quantifying the natural capital and ecosystem services of soils, Ecological Economics, 69, s. 1858-1868.

Douglas I., Bidin K., Balamurugan G., Chappell N.A., Walsh R.P.D., Greer T., Sinun W., 1999, The role of extreme events in the impacts of selective tropical forestry on erosion during harvesting and recovery phases at Danum Valley, Sabah, Philosophical Transactions of the Royal Society of London, 354, s. 1749-1761.

Elliot W.J., Page-Dumroese D., Robichaud P.R., 1999, The Effects of Forest Management on Erosion and Soil Productivity. Proceedings of the Symposium on Soil Quality and Erosion Interaction, Keystone, CO, July 7, 1996, Soil and Water Conservation Society, Ankeney, IA.

Endo T., Tsuruta T., 1969, The effect of the tree's roots on the shear strength of soil. Annual Report, Hokkaido Branch Forest Experiment Station, Sapporo, s. 167-182.

Ezzati S., Najafi A., Rab M.A., Zenner E.K., 2012, Recovery of soil bulk density, porosity and rutting from ground skidding over a 20-year period after timber harvesting in Iran, Silva Fennica, 46, s. 521-538.

Fahey B.D., Coker R.J., 1989, Forest road erosion in the granite terrain of Southwest Nelson, New Zealand, Journal of Hydrology, 28, 2, s. 123-141.

Foltz R.B., Burroughs E.R., 1990, Sediment Production from Forest Roads with Wheel Ruts, [w:] Watershed Planning and Analysis in Action Symposium, Proceedings of IR Conference Watershed Mgt/IR Div/ASCE Durango, CO, 9-11.06.1990, s. 266-275.

Fredriksen R.L., 1970, Erosion and sedimentation following road construction and timber harvest on unstable soils in three small western Oregon watersheds. Research Paper PNW-104, USDA Forest Service, Pacific Northwest Forest and Range Experiment Station, Portland, OR, U.S.

Frey B., Rüdt A., Sciacca S., Matthies D., 2009, Compaction of forest soils with heavy logging machinery affects soil bacterial community structure, European Journal of Soil Biology, 45, s. 312-320.

Froehlich H., 1979, Soil compaction from logging equipment: effects on growth of young ponderosa pine, Journal of Soil and Water Conservation, 34, s. 276-278.

Froehlich H., Miles D., Robbins R., 1985, Soil bulk density recovery on compacted skid trails in central Idaho, Soil Science Society of America Journal, 49, s. 1015-1017.

Froehlich W., 1975, Dynamika transportu fluwialnego Kamienicy Nawojowskiej, Prace Geograficzne, 114, IGiPZ PAN, Warszawa. 
Froehlich W., 1982, Mechanizm transportu fluwialnego i dostawy zwietrzelin do koryta w górskiej zlewni fliszowej, Prace Geograficzne, 143, IGiPZ PAN, Warszawa.

Froehlich W., Słupik J., 1986, Rola dróg w kształtowaniu spływu i erozji w karpackich zlewniach fliszowych, Przegląd Geograficzny, 58, 1-2, s. 67-87.

Froehlich W., Walling D.E., 1997, The role of unmetalled roads as a sediment source in the fluvial systems of the Polish Flysch Carpathians, [w:] D.E. Walling, J.L. Probst (red.), Human Impact on Erosion and Sedimentation, IAHS Proceedings \& Reports, 245, s. 159-168.

Gerlach T., 1976, Współczesny rozwój stoków w polskich Karpatach fliszowych, Prace Geograficzne, 122, IGiPZ PAN, Warszawa.

Giannetti F., Chirici G., Travaglini D., Bottalico F., Marchi E., Cambi M., 2017, Assessment of soil disturbance caused by forest operations by means of portable laser scanner and soil physical parameters, Soil Science Society of America Journal, 81, 6, s. 1577-1585.

Grace J.M., Skaggs R.W., Cassel D.K., 2006, Soil physical changes associated with forest harvesting operations on an organic soil, Soil Science Society of America Journal, 70, s. 503-509.

Gray D.H., Megahan W.F., 1981, Forest vegetation removal and slope stability in the Idaho Batholith, USDA Forest Service, Ogden, UT.

Greacen E.L., Sands R., 1980, Compaction of forest soils. A review, Australian Journal of Soil Research, 18, s. 163-189.

Green K., Alila Y., 2012, A paradigm shift in understanding and quantifying the effects of forest harvesting on floods in snow environments, Water Resources Research, 48, W10503.

Hartanto H., Prabhu R., Widayat A.S.E., Asdak C., 2003, Factors affecting runoff and soil erosion: plot-level soil loss monitoring for assessing sustainability of forest management, Forest Ecology and Management, 180, s. 361-374.

Hartmann M., Niklaus P., Zimmermann S., Schmutz S., Kremer J., Abarenkov K., Lüscher P., Widmer F., Frey B., 2014, Resistance and resilience of the forest soil microbiome to logging-associated compaction, ISME Journal, 8, s. 226-244.

Haydon S.R., Jayasuriya M.D.A., O'Shaughnessy P.J., 1991, The effect of vehicle use and road maintenance on erosion from unsealed roads in forests: the road 11 experiment, Melbourne Water, Melbourne, Victoria.

Heinimann H., 2007, Forest operations engineering and management - the ways behind and ahead of a scientific discipline, Croatian Journal of Forest Engineering, 28, s. 107-121.

Helms J.A., Hipkin C., 1986, Effects of soil compaction on tree volume in a California ponderosa pine plantation, Western Journal of Applied Forestry, 1, s. 121-124.

Horn R., Vossbrink J., Peth S., Becker S., 2007, Impact of modern forest vehicles on soil physical properties, Forest Ecology and Management, 248, s. 56-63.

Hoyt W.G., Troxell H.C., 1932, Forests and streamflow, Proceedings of the American Society of Civil Engineers, 58, s. 1037-1066.

Jakob M., 2000, The impacts of logging on landslide activity at Clayoquot Sound, British Columbia, Catena, 38, 4, s. 279-300.

Jansson K., Johansson J., 1998, Soil changes after traffic with a tracked and a wheeled forest machine: a case study on a silt loam in Sweden, Forestry, 71, s. 57-66.

Johnson M.G., Beschta R.L., 1980, Logging, infiltration capacity, and surface erodibility in western Oregon, Journal of Forestry, 78, s. 334-337.

Jones J., Grant G.E., 1996, Peak flow responses to clear cutting and roads in small and large basins, western Cascades, Oregon, Water Resources Research, 32, s. 959-974. 
Kijowska-Strugała M., 2015, Transport zawiesiny w warunkach zmieniajacej się antropopresji w zlewni Bystrzanki (Karpaty fliszowe), Prace Geograficzne, 247, IGiPZ PAN, Warszawa.

Kijowska-Strugała M., Bucała-Hrabia A., Demczuk P., 2018, Long-term impact of land use changes on soil erosion in an agricultural catchment (in the Western Polish Carpathians), Land Degradation and Development, 29, 6, s. 1871-1884.

Kochenderfer J.N., Helvey J.D., 1987, Using gravel to reduce soil losses from minimum-standard forest roads, Journal of Soil Water Conservation, 42, s. 46-50.

Kozlowski T.T., 1999, Soil compaction and growth of woody plants, Scandinavian Journal of Educational Research, 14, s. 596-619.

Krieger J.D., 2001, Economic Value of Forest Ecosystem Services: A Review, The Wilderness Society, Washington DC.

Kroczak R., 2010, Geomorfologiczne i hydrologiczne skutki funkcjonowania dróg polnych na Pogórzu Ciężkowickim, Prace Geograficzne, 225, IGiPZ PAN, Warszawa.

Kuraś P.K., Alila Y., Weiler M., 2012, Forest harvesting effects on the magnitude and frequency of peak flows can increase with return period, Water Resources Research, 48, s. 1-19.

La Marche J.L., Lettenmaier D.P., 2001, Effects of forest roads on flood flows in the Deschutes River, Washington, Earth Surface Processes and Landforms, 26, s. 115-134.

LaHusen R.G., 1984, Characteristics of management-related debris flows, northwestern California, [W:] C.L. O'Loughlin, A.J. Pearce (red.), Proceedings of the Symposium on Effects of Forest Land Use on Erosion and Slope Stability, East-West Center, University of Hawaii, Honolulu, s. 139-145.

Larsen M.C., Parks J.E., 1997, How wide is a road? The association of roads and mass-wasting in a forested montaine environment, Earth Surface Processes and Landforms, 22, s. 835-848.

Malmer A., 1996a, Hydrological effects and nutrient losses of forest plantation establishment on tropical rainforest land in Sabah, Malaysia, Journal of Hydrology, 174, s. 129-148.

Malmer A., 1996b, Observations of slope processes in a tropical rain forest environment before and after forest plantation establishment, [w:] M.G. Anderson, S.M. Brooks (red.), Advances in Hillslope Processes, 2, John Wiley \& Sons, Chichester, UK, s. 961-973.

McNabb D., Startsev A., Nguyen H., 2001, Soil wetness and traffic level effects on bulk density and air-filled porosity of compacted boreal forest soils, Soil Science Society of America Journal, 65, s. $1238-1247$.

Megahan W.F., 1972, Subsurface flow interception by a logging road in mountains of central Idaho, [w:] Proceedings of the National Symposium on Watersheds in Transition, American Water Resources Association, Fort Collins, CO, s. 350-356.

Megahan W.F., 1983, Hydrologic effects of clearcutting and wildfire on steep granitic slopes in Idaho, Water Resources Research, 19, 3, s. 811-819.

Megahan W.F., 1987, Effects of forest roads on watershed function in mountainous areas, [W:] A.S. Balasubramaniam, D.T. Bergado, S. Chandra, P. Nutalaya (red.), Environmental Geotechnics and Problematic Soils and Rocks, A.A. Balkema, Rotterdam, The Netherlands, s. 335-348.

Megahan W.F., Kidd W.J., 1972, Effects of logging roads on sediment production rates in the Idaho batholith. Research Paper INT-123, USDA Forest Service, Intermountain Forest and Range Experiment Station, Ogden, UT.

Montgomery D., 1994, Road surface drainage, channel initiation, and slope instability, Water Resources Research, 30, 6, s. 1925-1932.

Noguchi S., Abdul Rahim N., Zulkifli Y., Tani M., Sammori T., 1997, Rainfall-runoff responses and roles of soil moisture variations to the response in tropical rain forest, Bukit Tarek, Malaysia, Journal of Forest Research, 2, s. 125-132. 
Negishi J., Sidle R., Ziegler A., Noguchi S., Abdul Rahim N., 2008, Contribution of intercepted subsurface flow to road runoff and sediment transport in a logging-disturbed tropical catchment, Earth Surface Processes and Landforms, 33, s. 1174-1191.

O'Loughlin C.L., 1972, The stability of steepland forest soils in the Coast Mountains, southwest British Columbia, University of British Columbia, Vancouver (praca doktorska).

O'Loughlin C.L., Pearce A.J., 1976, Influence of Cenozoic geology on mass movement and sediment yield response to forest removal, North Westland, NZ, Bulletin of the International Association of Engineering Geology, 14, s. 41-46.

Ortyl B., Ćwik A., Kasprzyk I., 2018, What happens in a Carpathian catchment after the sudden abandonment of cultivation?, Catena, 166, s. 158-170.

Packer P.E., 1967, Criteria for designing and location roads to control sediment, Forest Science, 13, s. 1-18.

Piehl B.T., Beschta R.L., Pyles M.R., 1988, Ditch-relief culverts and low-volume forest roads in the Oregon Coast Range, Northwest Science, 62, 3, s. 91-98.

Reid L.M., Dunne T., 1984, Sediment production from forest road surfaces, Water Resources Research, 20, 11, s. 1753-1761.

Reid L.M., 1981, Sediment production from gravel-surfaced forest roads, Clearwater basin, Washington. FRI-UW-8108, Fisheries Research Institute, University of Washington, Seattle.

Sakals M., Sidle R.C., 2004, A spatial and temporal model of root strength in forest soils, Canadian Journal of Forest Research, 34, s. 950-958.

Sidle R.C., Pearce A.J., O'Loughlin C.L., 1985, Hillslope Stability and Land Use, Water Resources Monograph, 11. American Geophysical Union, Washington, DC.

Sidle R.C., Sasaki S., Otsuki M., Noguchi S., Abdul Rahim N., 2004, Sediment pathways in a tropical forest: effects of logging roads and skid trails, Hydrological Processes, 18, s. 703-720.

Sidle R.C., Ziegler A.D., Negishi J.N., Nik A.R., Siew R., Turkelboom F., 2006, Erosion processes in steep terrain - truths, myths, and uncertainties related to forest management in Southeast Asia, Forest Ecology and Management, 224, s. 199-225.

Slinski K.M., Hogue T.S., Porter A.T., McCray J.E., 2016, Recent bark beetle outbreaks have little impact on streamflow in the Western United States, Environmental Research Letters, 11.

Soja R., 2002, Hydrologiczne aspekty antropopresji w polskich Karpatach, Prace Geograficzne, 186, IGiPZ PAN, Warszawa.

Startsev A.D., McNabb D.H., 2000, Effects of skidding on forest soil infiltration in west-central Alber$\mathrm{ta}$, Canadian Journal of Soil Science, 80, s. 617-624.

Stednick J.D., 1996, Monitoring the effects of timber harvest on annual water yield, Journal of Hydrology, 176, s. 79-95.

Steinbrenner C.E., Gessel S.P., 1955, The effect of tractor logging on physical properties of some forest soils in Southwestern Washington, Soil Science Society of America Journal, 19, s. 372-376.

Swift L.W. Jr. 1984a, Gravel and grass surfacing reduces soil loss from mountain roads, Forest Science, 30, 3, s. 657-670.

Swift L.W. Jr. 1984b, Soil losses from roadbeds and cut and fill slopes in the southern Appalachian Mountains, Southern Journal of Applied Forestry, 8, 4, s. 209-215.

Thakur V.C., 1996, Landslide Hazard Management and Control in India, International Center for Integrated Mountain Development, Kathmandu, Nepal.

Troendle C.A., King R.M., 1985, The effect of timber harvest on the Fool Creek watershed, 30 years later, Water Resources Research, 21, s. 1915-1922. 
Tsukamoto Y., Ohta T., 1988, Runoff processes on a steep forested slope, Journal of Hydrology, 102, s. $165-178$.

Wałdykowski P., Krzemień K., 2013, The role of road and footpath networks in shaping the relief of middle mountains on the example of the Gorce Mountains (Poland), Zeitschrift für Geomorphologie, 57, 4, s. 429-470.

Wemple B.C., Jones J.A., Grant G.E., 1996, Channel network extension by logging roads in two basins, western Cascades, Oregon, Water Resources Bulletin, 32, 6, s. 1195-1207.

Wemple B.C., Swanson F.J., Jones J.A., 2001, Forest roads and geomorphic process interactions, Cascade Range, Oregon, Earth Surface Processes and Landforms, 26, s. 191-204.

Wert S., Thomas B.R., 1981, Effects of skid roads on diameter, height, and volume growth in Douglas-fir, Soil Science Society of America Journal, 45, s. 629-632.

Wronski E.B., 1984, Impact of tractor thinning operations on soils and tree roots in a Karri forest, Western Australia, Australian Forest Research, 14, s. 319-332.

Wu W., Sidle R.C., 1995, A distributed slope stability model for steep forested hillslopes, Water Resources Research, 31, 8, s. 2097-2110.

Zemke J., 2016, Runoff and soil erosion assessment on forest roads using a small scale rainfall simulator, Hydrology, 3, 25.

Zenner E.K., Fauskee J.T., Berger A.L., Puettmann K.I., 2007, Impacts of skidding traffic intensity on soil disturbance, soil recovery, and aspen regeneration in north central Minnesota, Northern Journal of Applied Forestry, 24, s. 177-183.

\section{Summary}

This work should acquaint Polish readers with the current state of knowledge on the impact of that the management of mountain forests exerts on soil and on the circulation of water and matter, including via such phenomena as erosion, sediment transport and flooding. It draws abundantly on foreign review papers on specific issues, at the same time augmenting the theses formulated with findings from most recent works and relating to Polish conditions. This literature review has provided a basis for it to be concluded that:

1. forest management, and above all the associated roads and skid trails, accelerate both water erosion and landslide processes in mountainous areas;

2. the movement of matter along forest roads (by both of the above mechanisms) is usually one to more than two orders of magnitude greater than that occurring on steep forested slopes;

3. unpaved forest roads, skid trails and wood-storage areas are the main sources of sediment in forest areas, while paved roads contribute to accelerated surface runoff;

4. the type and location of roads in mountain forest have a significant impact on the intensity of water erosion and landslides processes, as well as peak flows and resulting flood risk in lower locations;

5. roads and skid trails leading along the slope gradient and directly crossing roads and streams intensify further both erosion and the deposition of sediments into streams; 
6. the network of forest roads may contribute by up to several percent to increases in peak flows, as well as the resulting flash floods;

7. in the years immediately following clear-cutting, a two- to four-fold increase in the frequency of large flooding events is to be anticipated;

8. annual streamflow usually increases significantly where at least $20 \%$ of the tree basal area in a forest is removed;

9. the return of the hydrological system to its pre-harvest state is extremely slow (lasting up to 80 years);

10. there has recently been no universal confirmation of previously demonstrated associations between streamflow increase in mountain catchments and reductions in plant cover. 